\title{
Protective Action of Neurotrophic Factors and Estrogen against Oxidative Stress-Mediated Neurodegeneration
}

\author{
Tadahiro Numakawa, ${ }^{1,2}$ Tomoya Matsumoto, ${ }^{2,3}$ Yumiko Numakawa, ${ }^{4}$ Misty Richards, ${ }^{1,5}$ \\ Shigeto Yamawaki, ${ }^{2,3}$ and Hiroshi Kunugi ${ }^{1,2}$ \\ ${ }^{1}$ Department of Mental Disorder Research, National Institute of Neuroscience, National Center of Neurology and Psychiatry, \\ Tokyo 187-8502, Japan \\ ${ }^{2}$ Core Research for Evolutional Science and Technology Program (CREST), Japan Science and Technology Agency (JST), \\ Saitama 332-0012, Japan \\ ${ }^{3}$ Department of Psychiatry and Neurosciences, Division of Frontier Medical Science, Graduate School of Biomedical Sciences, \\ Hiroshima University, 1-2-3 Kasumi, Minami-ku, Hiroshima 734-8551, Japan \\ ${ }^{4}$ Peptide-prima Co., Ltd., 1-25-81, Nuyamazu, Kumamoto 861-2102, Japan \\ ${ }^{5}$ The Center for Neuropharmacology and Neuroscience, Albany Medical College, Albany, NY 12208, USA
}

Correspondence should be addressed to Tadahiro Numakawa, numakawa@ncnp.go.jp

Received 11 January 2011; Revised 28 February 2011; Accepted 29 March 2011

Academic Editor: Laurence D. Fechter

Copyright ( $\odot 2011$ Tadahiro Numakawa et al. This is an open access article distributed under the Creative Commons Attribution License, which permits unrestricted use, distribution, and reproduction in any medium, provided the original work is properly cited.

Oxidative stress is involved in the pathogenesis of neurodegenerative disorders such as Alzheimer's disease, Parkinson's disease, and Huntington's disease. Low levels of reactive oxygen species (ROS) and reactive nitrogen species (RNS) are important for maintenance of neuronal function, though elevated levels lead to neuronal cell death. A complex series of events including excitotoxicity, $\mathrm{Ca}^{2+}$ overload, and mitochondrial dysfunction contributes to oxidative stress-mediated neurodegeneration. As expected, many antioxidants like phytochemicals and vitamins are known to reduce oxidative toxicity. Additionally, growing evidence indicates that neurotrophic factors such as brain-derived neurotrophic factor (BDNF) and estrogens significantly prevent neuronal damage caused by oxidative stress. Here, we review and discuss recent studies addressing the protective mechanisms of neurotrophic factors and estrogen within this system.

\section{Introduction}

It is well established that the brain consumes a large quantity of oxygen and glucose [1-5]. Brain neurons utilize such nutrients, requiring a consistent and steady supply in order to function appropriately. Not surprisingly, brain neurons are vulnerable to oxidative stress [6], which threatens the overall functionality of the brain. Though various systems protecting against oxidative toxicity exist in the brain at cellular and molecular levels, a disruption of the defensive system may be involved in neurological deficits observed in neurodegenerative diseases. Indeed, many studies suggest that oxidative toxicity is related to Alzheimer's disease (AD), Parkinson's disease (PD), and Huntington's disease (HD) [7]. In addition, a correlation between an accumulation of oxidative stress and aging has also been established [8]. Thus, it is important to clarify the detailed relationship between oxidative stress and cellular damage in neurodegenerative diseases and the aging process. In the cellular and molecular mechanisms underlying oxidative stress-induced cell death, it is well known that excitotoxicity, $\mathrm{Ca}^{2+}$ overload, mitochondrial dysfunction, and the stimulation of intracellular signaling cascades play a role [9]. As expected, antioxidants including many phytochemicals and vitamins have been found to support the survival of neurons under oxidative stress.

Brain-derived neurotrophic factor (BDNF), a member of the neurotrophin family, is known to be a strong survivalpromoting factor against various neuronal insults. As a result, the molecular mechanisms underlying neurotrophindependent survival promotion when exposed to oxidative stress have been extensively studied. BDNF plays a critical 
role in cell proliferation, cell differentiation, neuronal protection, and the regulation of synaptic function in the central nervous system (CNS) via stimulating key intracellular signaling cascades $[10,11]$. In addition to BDNF, glial cell linederived neurotrophic factor (GDNF) and hepatocyte growth factor (HGF) are also effective for neuronal survival $[12,13]$. Furthermore, estrogens, which regulate synaptic plasticity in addition to sex differentiation of the brain [14-16], are found to exert protective actions against toxic conditions such as oxidative stress [17]. Here, we review the current issues concerning protective functions of neurotrophic factors and estrogen on neurons under oxidative stress.

\section{The Role of Oxidative Stress in Neurodegenerative Diseases}

Low levels of ROS and RNS have a physiological effect on cellular functions including neuronal plasticity [18]. However, in excess, ROS/RNS cause oxidation/nitrosylation of lipids, proteins, and nucleic acids, resulting in neuronal cell death (Figure 1). Such damage occurs as a result of either overproduction of ROS/RNS or reduced activity of enzymatic and nonenzymatic antioxidants. Thus, the delicate balance between pro- and antioxidant reactions is critical for maintaining normal neuronal function.

Oxidative stress-mediated toxicity may be closely related to the pathogenesis of neurodegenerative diseases such as $\mathrm{AD}, \mathrm{PD}$, and $\mathrm{HD}$ [7]. For example, in $\mathrm{AD}$ brains, markers for protein oxidation (protein carbonyls and 3-nitrotyrosine (3-NT)), lipid oxidation (4-hydroxy-2' -nonenal (4HNE)), and DNA oxidation (8-hydroxy-2-deoxyoguanine $(8-\mathrm{OHdG}))$ are elevated [19]. Indeed, the accumulation of amyloid beta $(\mathrm{A} \beta)$, a hallmark of $\mathrm{AD}$, produces $\mathrm{ROS}$ including hydrogen peroxide $\left(\mathrm{H}_{2} \mathrm{O}_{2}\right)$ in the presence of $\mathrm{Fe}^{3+}$ or $\mathrm{Cu}^{2+}$ [20-22], but see [23]. In $\mathrm{PD}$ brains, in which a selective and progressive loss of dopamine (DA) neurons in the substantia nigra pars compacta occurs, 4HNE, protein carbonyls, 3-NT, and 8-OHdG are all increased while glutathione (GSH, a major intracellular antioxidant) is decreased [24]. Interestingly, 4-HNE covalently binds to alpha-synuclein ( $\alpha$-Syn), a central protein in PD pathogenesis, resulting in neurotoxic effects on DAergic and GABAergic neuronal cultures [25]. Similarly, HD brains (where significant neuronal loss in the striatum and cortex is observed) demonstrate elevated 3-NT, lipofuscin (a product of unsaturated fatty acid peroxidation), malondialdehyde (a marker for lipid oxidation), and 8-OHdG [26]. Reduced levels of GSH were also confirmed in cultured neurons from mice expressing mutant Huntingtin protein (Htt140Q/140Q) [27].

Oxidative toxicity is also involved in cerebral ischemia/ reperfusion injury. Brain regions and types of neurons that are vulnerable to ischemia are limited. It may be because cerebral blood flow is highly spatiotemporally modulated [2], and this view could also be important to understand why specific types of neurons in different brain regions are affected in each neurodegenerative disease. In addition, a large body of evidence suggests that accumulation of oxidative stress-dependent damage occurs during normal aging, which may cause a noticeable decline in cognitive function [8, 28]. Considering that cognitive deficits are observed in neurodegenerative diseases such as AD as well, a common mechanism underlying oxidative stress-mediated neuronal cell death may exist. In the following section, we summarize the current knowledge concerning oxidative stress-mediated neuronal cell death.

\section{Oxidative Stress-Mediated Neuronal Cell Death}

3.1. Mitochondrial Dysfunction, $\mathrm{Ca}^{2+}$ Overload and Excitotoxicity. Apoptosis, a prototypic form of programmed cell death, is a major mode of cell death in neurodegenerative diseases. Various mechanisms including excitotoxicity, $\mathrm{Ca}^{2+}$ overload, mitochondrial dysfunction, endoplasmic reticulum stress, and oxidative stress have been found to contribute to apoptosis [9] (Figure 1). Mitochondria produce low levels of ROS in a process known as cellular respiration through the electron transport chain (ETC). The ETC consists of five protein complexes (I-V), and a disruption of this electron transport system leads to excess generation of ROS [29]. Importantly, a number of studies reported possible involvement of mitochondrial dysfunction, including altered activity of the ETC, in patients and animal models for AD [30], PD [31], HD [32], and stroke [33]. Some reports suggest that patients with psychiatric disorders, such as schizophrenia [34], depression [35], and bipolar disorder [36], also display mitochondrial dysfunction.

In addition, mitochondria regulate/impact/affect $\mathrm{Ca}^{2+}$ homeostasis by sequestering excess cytosolic $\mathrm{Ca}^{2+}$ into their matrix (named $\mathrm{Ca}^{2+}$ loading). However, an uncontrolled $\mathrm{Ca}^{2+}$ loading may be involved in neurodegeneration. In a study investigating striatal mitochondria of Hdh150 knockin $\mathrm{HD}$ mice, a disrupted $\mathrm{Ca}^{2+}$ homeostasis was found [37]. Another study discovered that a deficiency of phosphatase and tensin homolog deleted on chromosome 10 (PTEN)-induced putative kinase 1 (PINK1, a mitochondrial kinase linked to familial PD) results in mitochondrial $\mathrm{Ca}^{2+}$ accumulation in cultured neurons [38]. Endoplasmic reticulum also regulates intracellular $\mathrm{Ca}^{2+}$ concentration through inositol-1,4,5-triphosphate receptors (InsP3Rs) and ryanodine receptors (RyRs). Interestingly, presenilin (PS) 1 and 2, genes involved in the pathogenesis of $\mathrm{AD}$, acted as a passive endoplasmic reticulum $\mathrm{Ca}^{2+}$ channel to maintain steady-state $\mathrm{Ca}^{2+}$ levels, which was disrupted by mutant PS1M146V and PS2-N141I $[39,40]$. These PS mutants enhanced the gating activity of InsP3Rs, leading to $\mathrm{A} \beta$ generation [41]. Furthermore, it was shown that $\mathrm{A} \beta$-containing senile plaques cause $\mathrm{Ca}^{2+}$ overload [42]. Taken together, it seems likely that mutant PSs and $\mathrm{A} \beta$ contribute to the disruption of $\mathrm{Ca}^{2+}$ homeostasis, which may cause mitochondrial dysfunction leading to neuronal degeneration [30].

Remarkably, nicotinamide adenine dinucleotide phosphate (NADPH) oxidase (Nox) may generate ROS in a mitochondria-independent manner. In cultured cortical neurons lacking p47(phox), a cytosolic subunit of 

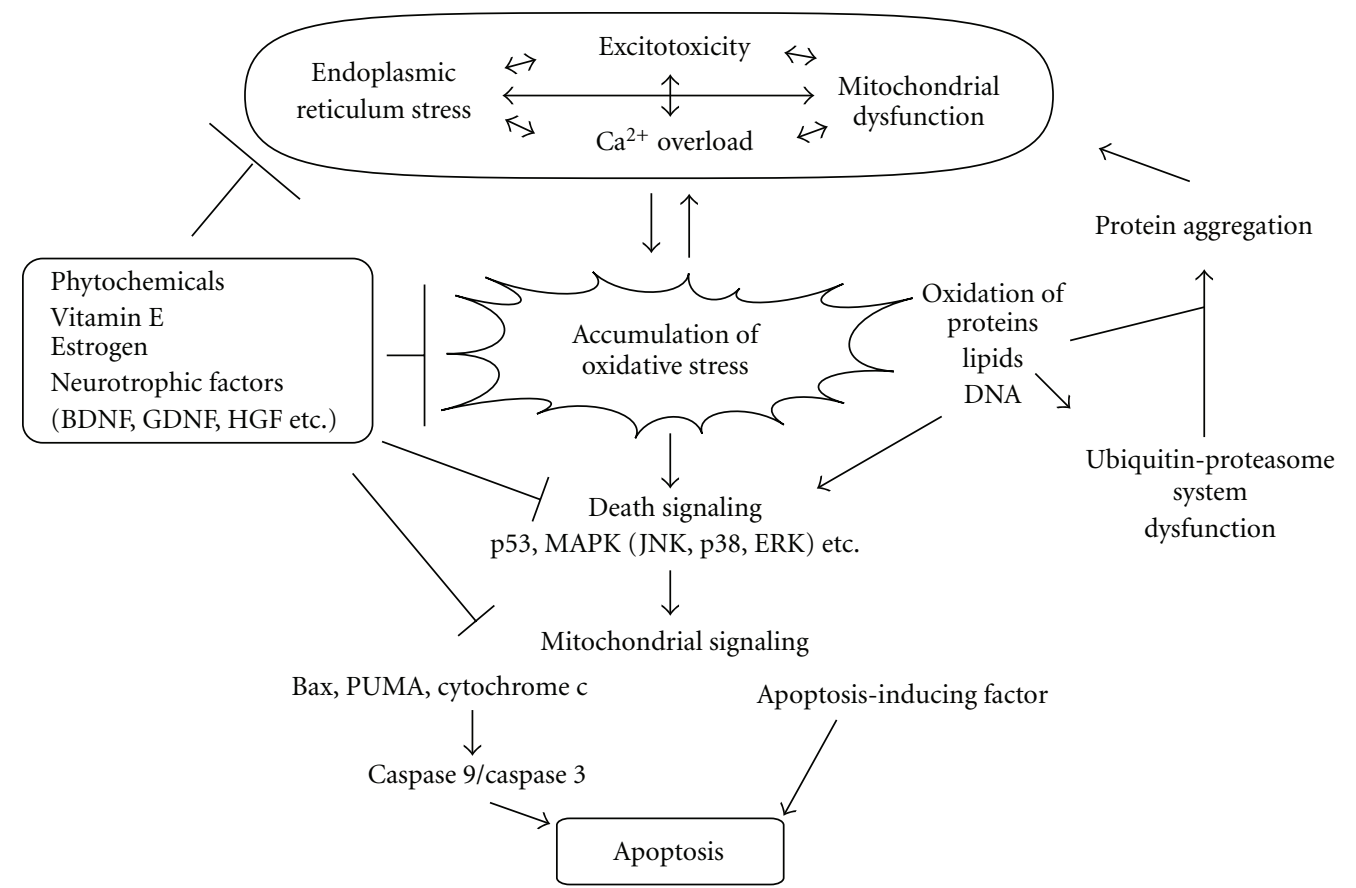

Figure 1: Mechanisms underlying oxidative stress-mediated neuronal apoptosis. Accumulation of oxidative stress is involved in the development/progression of neurodegenerative diseases. A number of events including excitotoxicity, mitochondrial dysfunction, Ca ${ }^{2+}$ overload, and endoplasmic reticulum stress are associated with excess reactive oxygen species (ROS) and reactive nitrogen species (RNS) generation. High levels of ROS/RNS lead to oxidation of proteins, lipids, and DNA. Oxidized lipids induce damage of the ubiquitinproteasome system (UPS). The UPS dysfunction and oxidation of proteins result in aggregation of proteins, recognized as a hallmark of several neurodegenerative diseases. Under oxidative stress, death signaling pathways (p53, mitogen-activated protein kinase (MAPK), etc.) are activated. Activation of p53 leads to induction of proapoptotic proteins such as Bax and p53-upregulated modulator of apoptosis (PUMA), followed by translocation of these proteins into mitochondria. Finally, mitochondrial cytochrome $c$ is released, which then stimulates the activation of caspase 9/caspase 3. Alternatively, mitochondria secrete apoptosis-inducing factor (AIF), leading to caspaseindependent apoptosis. As shown, recent studies suggest antioxidant effects of phytochemicals, vitamin E, estrogen, and neurotrophic factors including brain-derived neurotrophic factor (BDNF), glial cell line-derived neurotrophic factor (GDNF), and hepatocyte growth factor (HGF), leading to increased preservation of neuronal function.

Nox, extensive N-methyl-D-aspartic acid (NMDA) receptor activation failed to produce ROS, while $\mathrm{H}_{2} \mathrm{O}_{2}$ or the mitochondrial complex III inhibitor (antimycin) increased ROS [43]. Furthermore, ROS production and oxidative damage in the hippocampal CA1 neurons after ischemia were dramatically attenuated in mice either treated with Nox inhibitor or lacking gp91(phox), another Nox subunit [44]. Considering the fact that overactivation of NMDA receptors occurs in ischemia [45], it is possible that NMDA-mediated excitotoxicity may cause mitochondriaindependent, but Nox-dependent, ROS production in cerebral ischemia/reperfusion injury.

3.2. Signaling Pathways in Apoptosis. p53, a transcription factor, is activated by ROS, and induces the upregulation of mitochondrial proapoptotic proteins including B-cell lymphoma-2-associated X protein (Bax) and members of the B-cell lymphoma-2-homology 3 (BH3) family consisting of $\mathrm{BH} 3$ interacting death agonist (Bid), Nox activator 1 (Noxa), and p53-upregulated modulator of apoptosis (PUMA) [33]. Indeed, oxidative stressors including $\mathrm{H}_{2} \mathrm{O}_{2}$ increased Noxa, Bim, and PUMA (but not Bid) in cultured cortical neurons
[46]. Importantly, PUMA, but not Noxa or Bim, was involved in Bax-dependent apoptosis [46]. The contribution of p53/PUMA to delayed cell death of hippocampal neurons after stroke was also reported [47]. These studies suggest that p53-mediated PUMA expression may be a key event in neuronal apoptosis (Figure 1).

As the final step of apoptosis, cytochrome $\mathrm{c}$ is released from mitochondria via the permeability transition pore (PTP), which consists of the mitochondrial inner and outer membrane proteins including B-cell lymphoma-2 (Bcl-2) and Bax (Figure 1). Cytosolic cytochrome c participates in the formation of the apoptosome, a multiprotein complex including apoptosis protease-activating factor 1 (Apaf-1) and caspase-9, which activates caspase-3, an executioner in cell death [48]. On the other hand, apoptosis-inducing factor (AIF) is involved in mitochondria-mediated, but caspaseindependent, apoptosis [49] (Figure 1).

3.3. Antioxidative Factors. Considering that oxidative stress may be associated with the pathogenesis of neurodegenerative diseases, a key therapeutic intervention would be to block or delay accumulating oxidative stress levels via 
increasing the function of endogenous antioxidants and/or suppressing ROS production (Figure 1). Well-known antioxidants include glutathione precursor [50, 51], polyphenols [52-54], catechins [55], flavonoids [56], and sulfated polysaccharides [57]. As the toxicity of phytochemicals is low, these substances offer a new therapeutic approach against neurodegenerative diseases [58]. On the other hand, whether oxidative stress is a cause or consequence of neurodegenerative disease remains to be elucidated [7]. A growing body of evidence suggests that oxidative stress directly initiates and progresses to neuronal cell death. However, it is possible that accumulation of oxidative stress is easily induced in neurons weakened by other insults. Indeed, in the apoptotic process, many cellular events including mitochondrial dysfunction, $\mathrm{Ca}^{2+}$ overload, and excitotoxicity activate death signaling cascades (Figure 1). Such negative feedback loops may influence cell viability. These events probably occur in parallel and have an additive or synergic effect in the induction of cell death. Therefore, in addition to blocking accumulation of oxidative stress, inhibiting death-signaling cascades and activating survival signaling would also be effective. In the following section, we focus specifically on neurotrophic factors and steroid hormones that may exert a beneficial influence.

\section{Neurotrophins and Oxidative Stress in Neurodegenerative Diseases}

As mentioned above, oxidative stress may be involved in the onset of $\mathrm{HD}, \mathrm{AD}, \mathrm{PD}$, and amyotrophic lateral sclerosis (ALS) [7, 9]. Interestingly, neurotrophic factors, including neurotrophins, may also be associated with the pathology of these neurodegenerative diseases. For example, both mRNA and protein levels of BDNF are decreased in patients and animal models of HD [59-61]. In addition, the level of TrkB (tropomyosin-related kinase B), a high affinity receptor for BDNF, is also reduced in knockin HD striatal cells, in which mutant huntingtin with 111 glutamines (7 glutamines in normal) is expressed [62]. Following TrkB activation stimulated by BDNF, the mitogenactivated protein kinase/extracellular signal-regulated protein kinase (MAPK/ERK), phospholipase $\mathrm{C} \gamma$ (PLC $\gamma)$, and phosphatidylinositol 3-kinase (PI3K) pathways are primarily triggered [10]. In the knock-in HD striatal cells, a downregulation of ERK signaling occurred, while PI3K/Akt and PLC $\gamma$ pathways were intact. Such a decrease in ERK signaling in these striatal cells resulted in an increase in the cell death caused by $\mathrm{H}_{2} \mathrm{O}_{2}$ [63]. As expected, it was revealed that BDNF, neurotrophin-3 (NT-3), and NT-4/5 prevent neuronal cell death in an animal model of HD [64].

Recent reports suggest that the upregulation of BDNF expression/function plays a role in neuroprotection within AD models. Counts and Mufson showed that noradrenaline (NA) is neuroprotective against $\mathrm{A} \beta$-dependent toxicity in human NTera-2N (hNT) neurons and rat hippocampal neurons [65]. NA prevented an increase in ROS caused by $A \beta$. Notably, coapplication with functional blocking antibodies for BDNF or nerve growth factor (NGF) significantly inhibited the NA-dependent protective effect against
$\mathrm{A} \beta$ toxicity [65]. As $\mathrm{AD}$ is well known as an age-related neurodegenerative illness, the senescence-accelerated mouse prone 8 (SAMP8) mice, which show age-related impairment of cognitive function, is a useful model of $\mathrm{AD}$ [66]. Using the SAMP8 mice, Zhao et al. investigated the effect of ginsenoside, a component of ginseng, on memory [67]. They reported that chronic treatment with ginsenoside prevented loss of memory in aged SAMP8 mice. Such a treatment with ginsenoside decreased the $A \beta$ and, in turn, increased antioxidation and synaptic plasticity-related proteins such as BDNF [67].

Oxidative stress may damage nigral DA neurons, resulting in the onset of PD. Under oxidative stress, heme oxygenase-1 (HO-1) increases and exerts a positive effect on nigral DA neurons. Overexpression of $\mathrm{HO}-1$ in rat substantia nigra rescued DA neurons from cell death caused by 1-methyl-4-phenylpyridinium $(\mathrm{MPP}(+))$, which is an inhibitor for mitochondrial complex I and is well known to produce PD symptoms. After HO-1 overexpression, GDNF, in addition to BDNF, was upregulated [68]. Additionally, it was reported that bilirubin, a downstream product of HO1 , increased GDNF and BDNF expression through ERK and PI3K/Akt pathways [69]. These results suggest that HO1 protects neurons through increasing these neurotrophic factors. A role of the novel DA D3 receptor agonist D264 in neuroprotection was reported [70]. In the 1-methyl4-phenyl-1,2,3,6-tetrahydropyridine (MPTP, an inhibitor of mitochondrial complex I)-induced neurodegeneration mouse model for PD, D-264 treatment improved behavioral performance and reduced neuronal loss. Remarkably, the D264 treatment induced an upregulation of BDNF and GDNF in MPTP-treated animals [70]. Finally, using an in vitro system, L-theanine (a glutamate analog) was shown to promote SH-SY5Y cell survival and inhibited downregulation of both BDNF and GDNF under neurotoxicant (rotenone and dieldrin) application [71]. Generally, GDNF and BDNF are important for survival/morphological change of DA neurons, and both have a recovery effect on PD-like behavior $[12,72,73]$. Taken together, it is possible that upregulation of growth factors including BDNF and GDNF is necessary for the prevention of DA neuronal damage.

\section{BDNF and Oxidative Stress-Induced Cell Death}

BDNF exerts protective effects against neuronal cell death by activating intracellular signaling cascades via TrkB $[10$, 11, 74]. Interestingly, trypanosome trans-sialidase (TS, sialic acid-transferring enzyme) mimics neurotrophins. Woronowicz et al. showed that TS induced phosphorylation of TrkB in rat pheochromocytoma (PC12) cells expressing TrkB and promoted cell survival under $\mathrm{H}_{2} \mathrm{O}_{2}$ stress [75]. The PI3K pathway was important for TS-mediated survival promotion. On the other hand, BDNF protects cultured cortical neurons from NMDA- or $\mathrm{H}_{2} \mathrm{O}_{2}$-induced cell death via suppressing the MAPK pathway [76]. Once exposed to NMDA or $\mathrm{H}_{2} \mathrm{O}_{2}$, retinoblastoma protein and E2F1 transcription factor, which are cell cycle regulators, 
were stimulated. BDNF inhibited such activation of cell cycle regulators, suggesting that the prevention of cell cycle reentry is involved in BDNF function during oxidative stress [76]. Moreover, the activation of cyclic adenosine $3^{\prime}, 5^{\prime}$-monophosphate (cAMP)-responsive element-binding protein (CREB) is involved in BDNF neuroprotection. Transgenic mice expressing A-CREB, a dominant negative form of CREB, showed a significant increase in vulnerability to seizure activity. The A-CREB mice demonstrated increased ROS levels and decreased neuroprotection by BDNF application, suggesting that CREB is an essential upstream effector of neuroprotection against oxidative toxicity [77]. Importantly, CREB also regulates the transcriptional production of BDNF [78]. The BDNF gene consists of nine exons, and exon IX corresponds to the common open reading frame of the protein. The remaining exons have distinct promoters, respectively. Thus, the transcript of BDNF consists of one of eight $5^{\prime}$ untranslated exons (exon I VIII) and $3^{\prime}$ exon IX [79]. Interestingly, the action of CREB via promoter IV is critical for experience-dependent production of BDNF [80]. Therefore, positive-feedback mechanisms may be involved in BDNF-mediated neuroprotection.

As mentioned, BDNF seems to be beneficial in the therapeutic approach to neurodegenerative diseases. However, previous clinical trials have revealed numerous side effects of neurotrophins as well as their poor penetration through the blood brain barrier, making it very difficult to use these proteins as a drug [81]. Therefore, many studies have been performed in an effort to find a drug that upregulates BDNF. In SH-SY5Y cells after $\mathrm{H}_{2} \mathrm{O}_{2}$ application, tripterygium regelii extract (TRE), a traditional herbal medicine, increased tyrosine hydroxylase, a dopaminergic marker, and BDNF [82]. TRE was shown to repress the upregulation of proapoptotic proteins Bax and caspase3 , while inhibiting downregulation of antiapoptotic Bcl2 under $\mathrm{H}_{2} \mathrm{O}_{2}$ application [82]. Sonic hedgehog ( $\mathrm{SHH}$ ) protein, a member of the Hedgehog family of signaling molecules [83], is putatively involved as a neuroprotective agent in oxidative stress-related neurodegenerative disease and ischemia. After $\mathrm{H}_{2} \mathrm{O}_{2}$ exposure, the $\mathrm{SHH}$ pathway was stimulated in cultured cortical neurons, and the increase in SHH pathway activation was noticeably protective against cell death caused by $\mathrm{H}_{2} \mathrm{O}_{2}$ [84]. In that in vitro system, exogenous $\mathrm{SHH}$ increased levels of vascular endothelial growth factor (VEGF) and BDNF, as well as activity of superoxide dismutase (SOD) and Bcl-2 expression [84].

Positive effects of the antioxidant vitamin $\mathrm{E}$ on oxidative stress-mediated toxicity in vitro [85-87] and in vivo [88, 89] have been reported. Vitamin $\mathrm{E}$ has also been shown to exert beneficial effects against neurodegenerative diseases $[90,91]$. Our research demonstrates that pretreatment with vitamin $\mathrm{E}$ analogs including $\alpha$ - and $\gamma$-tocopherol $(\alpha \mathrm{T}$ and $\gamma \mathrm{T}$, respectively) and $\alpha$ - and $\gamma$-tocotrienol ( $\alpha \mathrm{T} 3$ and $\gamma \mathrm{T} 3$ ) protected cultured cortical neurons against $\mathrm{H}_{2} \mathrm{O}_{2}$-mediated neuronal cell death [92]. In our cultures, $\alpha \mathrm{T}$ stimulated the activation of both the ERK and PI3K pathways and caused the upregulation of Bcl-2. Importantly, $\alpha \mathrm{T}$-mediated survival and $\mathrm{Bcl}-2$ upregulation disappeared in the presence of inhibitors for ERK and PI3K signaling, suggesting the involvement of both pathways in neuroprotection by vitamin $\mathrm{E}$ analogs. However, the neuroprotection was not via BDNF signaling, as $\alpha \mathrm{T}$ unchanged TrkB activation and BDNF expression [92]. It would be interesting to examine possible contributions from other neurotrophic factors.

It is now critical to further investigate the mechanisms underlying the upregulation of BDNF and/or other effective growth factors in order to discover more efficacious medications. In general, BDNF levels are regulated by neuronal activity. In addition to the influx of $\mathrm{Ca}^{2+}$, neuronal activity, including glutamatergic regulation, contributes to the production and secretion of BDNF [93-98]. Change in the production and secretion of BDNF is thought to be involved in the activity-dependent synaptic plasticity in the CNS [99, 100]. Interestingly, two recent studies have demonstrated the role of synaptic activity in neuroprotection. In cultured hippocampal neurons, action potential bursting reduced the levels of p53, PUMA and Apaf1 [101]. Furthermore, NMDA receptor stimulation inhibited PUMA-mediated apoptosis via reducing levels of Apaf1 and procaspase-9 [102]. In support of these current studies, a previous study demonstrated that transcranial magnetic stimulation, which is well known to potentiate neuronal activity, inhibited toxic effects of 3-nitropropionic acid (3-NPA) (protein/lipid oxidations, reduction in activities of catalase, GSH peroxidase and succinate dehydrogenase, and GSH deficiency) and rescued the striatal neuronal loss in rats [103]. It is necessary to investigate whether or not such neuronal activity-mediated protection occurs via the upregulation of BDNF. Additionally, future studies investigating the role of neuronal activity in the expression of neurotrophic factors that are influenced by molecules that cross the blood brain barrier are needed.

Transplantation of growth factor-secreting cells may serve as an alternative method to treat neurodegenerative diseases. Indeed, the grafting of neurotrophin-secreting cell lines has been shown to protect neurons against quinolinateinduced cell death in an animal model of HD [64]. In addition, it was shown that erythropoietin-transduced human mesenchymal stromal cells (EPO-MSCs) played a neuroprotective role in the rat model for ischemic stroke [104]. In the EPO-MSCs, neurotrophic factors including BDNF and HGF were upregulated. The implantation of EPO-MSCs into ischemic rats reversed impairment in neurological function and infarct volumes [104]. Finally, a gene transfer approach may be a potentially effective strategy as well. In an in vivo cognitive dysfunction model induced by A $\beta$ injection, HGF gene transfer improved impairment of cognitive behavior. It was suggested that BDNF upregulation was involved in the positive action of HGF gene transfer [105]. Further investigation on the possible mechanisms underlying the $\mathrm{BDNF}$ upregulation is interesting.

\section{Estrogen Signaling and Oxidative Stress}

Estrogen, one of the sex steroids, has various roles in sex differentiation, neuroprotection, and synaptic plasticity [14$16,106]$. Furthermore, estrogenic protection from toxicity including excitotoxicity and oxidative stress is well studied [107-109]. Importantly, the maintenance of mitochondrial 
function is linked to estrogenic protection under toxic stress. Protein phosphatases influence activation levels of kinase signaling and of mitochondrial apoptosis-related proteins, and such intracellular mechanisms are closely associated with estrogenic protection [110].

Generally, estrogens are believed to regulate transcription of target genes via estrogen receptor $\alpha(\mathrm{ER} \alpha)$ and $\operatorname{ER} \beta$. Estrogens bind to $\operatorname{ER} \alpha$ and $\operatorname{ER} \beta$, exerting various effects via initiating diverse intracellular signaling cascades. Specifically, the discovery of ER $\beta$ prompted major developments leading towards the understanding of estrogenic function $[111,112]$. In addition, it has been recently suggested that estrogens also exert their effects via ER-mediated nongenomic or non-ERmediated functions.

Estrogens protect neurons from severe conditions including oxidative stress. $17 \beta$-estradiol (E2), one of the estrogens, reduces CA1 hippocampal cell death following global cerebral ischemia [113]. In that in vivo system, Nox activity and superoxide production in the hippocampal region were repressed by E2 application. Interestingly, extranuclear ER $\alpha$ dependent nongenomic function, including the activation of Akt, is involved in the E2 effect [113]. Xia et al. examined the effect of selective ER ligands on glutamate toxicity. In cultured cortical neurons, R, R-tetrahydrochrysene (R,RTHC, $\operatorname{ER} \beta$ antagonist and $\operatorname{ER} \alpha$ agonist) displays a neuroprotective effect against glutamate-induced cell death [114], suggesting an important role of $\mathrm{ER} \alpha$ in estrogen-mediated neuroprotection. On the other hand, a knockdown of ER $\beta$ induced a lower resting mitochondrial membrane potential in immortal hippocampal and primary hippocampal neurons [115]. The $\operatorname{ER} \beta$ knockdown resulted in maintenance of adenosine $5^{\prime}$-triphosphate (ATP) concentration, and decreased mitochondrial superoxide levels under $\mathrm{H}_{2} \mathrm{O}_{2}$ stress. As expected, the neuronal loss of ER $\beta$ knockdown cells diminished in the presence of oxidative stress caused by glutamate or $\mathrm{H}_{2} \mathrm{O}_{2}$ [115]. Recently, the novel function of GPR30, a G protein-coupled ER, has been reported. Gingerich et al. found that pretreatment with E2 decreased cell death caused by glutamate, which may be partially mediated by GPR30 [116].

It is possible that $\mathrm{ER} \beta$ regulates neuronal activity. As a result of neurotransmission, spontaneous $\mathrm{Ca}^{2+}$ oscillations occured and our group previously showed potentiation in glutamate-mediated $\mathrm{Ca}^{2+}$ oscillation after BDNF addition [117]. In our cortical cultures, voltage-dependent $\mathrm{Ca}^{2+}$ channels and ionotropic glutamate receptors contributed to the spontaneous $\mathrm{Ca}^{2+}$ oscillations, and BDNF-induced glutamate release was critical for the potentiation in the oscillations. Recently, Zhang et al. found that selective $\mathrm{ER} \beta$ agonists (not $\mathrm{ER} \alpha$ agonists) rapidly potentiated $\mathrm{Ca}^{2+}$ oscillations in neurons derived from embryonic stem cells and activated protein kinase $\mathrm{C}$ (PKC), Akt, and ERK pathways. Interestingly, nifedipine, a blocker of L-type voltagedependent $\mathrm{Ca}^{2+}$ channels, abolished these $\mathrm{ER} \beta$ actions [118], suggesting that estrogen regulates neuronal function via $\mathrm{ER} \beta$. Remarkably, membrane-localized $\operatorname{ER} \alpha$ activates mGluR5 signaling (one of the metabotropic glutamate receptors) to stimulate CREB in striatal neurons. Furthermore, both $\mathrm{ER} \alpha$ and $\mathrm{ER} \beta$ activate mGluR3 to attenuate L-type voltage-

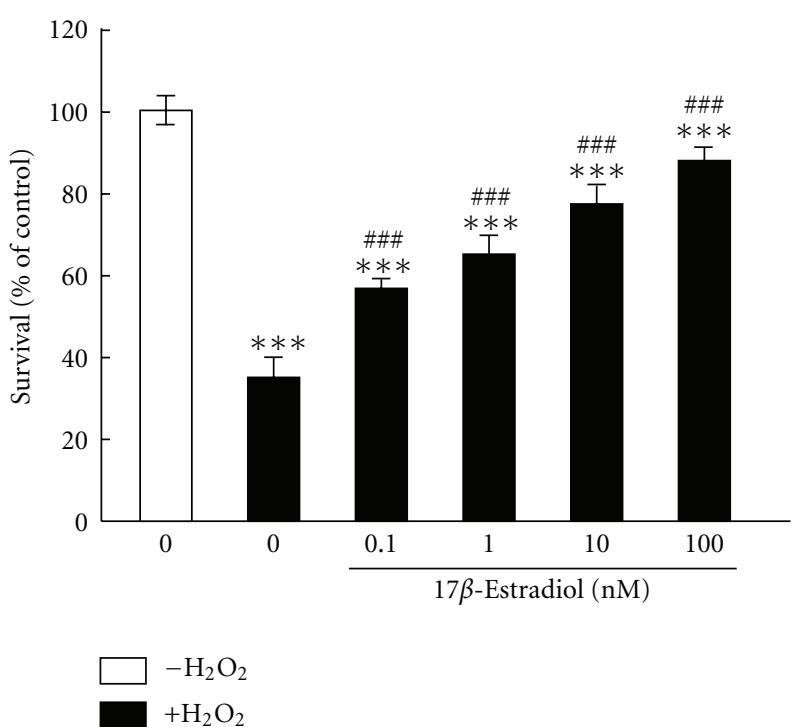

FIGURE 2: $17 \beta$-estradiol prevents cortical neurons from cell death caused by $\mathrm{H}_{2} \mathrm{O}_{2}$ exposure. Dissociated cortical neurons were prepared from cerebral cortex of postnatal 2-day-old rats. At 6 days in vitro, $17 \beta$-estradiol was applied at indicated concentrations. Twenty-four hours later, $\mathrm{H}_{2} \mathrm{O}_{2}$ (final $50 \mu \mathrm{M}$ ) was added to induce cell death. Following an additional twelve-hour culture, cell survival was determined using an MTT (tetrazolium salt) assay. Data represent mean \pm S.D. $(n=6)$. ${ }^{* * *} P<.001$ versus control (no $\left.\mathrm{H}_{2} \mathrm{O}_{2}\right)$. ${ }^{\# \#} \mathrm{P}<.001$ versus no estradiol $+\mathrm{H}_{2} \mathrm{O}_{2}$.

dependent $\mathrm{Ca}^{2+}$ channel-mediated CREB activation [119]. Considering that CREB is involved in the transcriptional production of BDNF [78], the action of these ERs may affect BDNF levels in neuronal cells.

\section{Estrogen and $\mathrm{Ca}^{2+}$ Homeostasis under Oxidative Stress}

Using cultured cortical neurons, we demonstrated the protective effect of E2 against cell death under oxidative stress caused by $\mathrm{H}_{2} \mathrm{O}_{2}$ [120] (Figure 2). Members of the MAPK family including c-jun N-terminal kinase (JNK) [121], p38 [122], and ERK [123, 124] play pivotal roles in neuronal apoptosis [125] (Figure 1). In our system, the exposure to $\mathrm{H}_{2} \mathrm{O}_{2}$ triggered the overactivation of the ERK pathway, leading to an abnormal increase in intracellular $\mathrm{Ca}^{2+}$ concentration (Figure 3 ). In general, perturbations of $\mathrm{Ca}^{2+}$ homeostasis are related to apoptosis in various cell populations [126-131]. In our neurons, the abnormal $\mathrm{Ca}^{2+}$ accumulation caused by $\mathrm{H}_{2} \mathrm{O}_{2}$ was significantly decreased by E2 pretreatment, or in the presence of U0126, an inhibitor for ERK signaling [120]. Recently, we reported that ERK signaling plays a role in maintaining adequate expression levels of glutamate receptors [132-134]. Importantly, chronic E2 treatment induced the downregulation of ionotropic glutamate receptor subunits including NR2A and GluR2/3. Such a decrease in glutamate receptor expression levels was also confirmed after U0126 addition. Indeed, such E2 treatment suppressed the overactivation of ERK pathway 


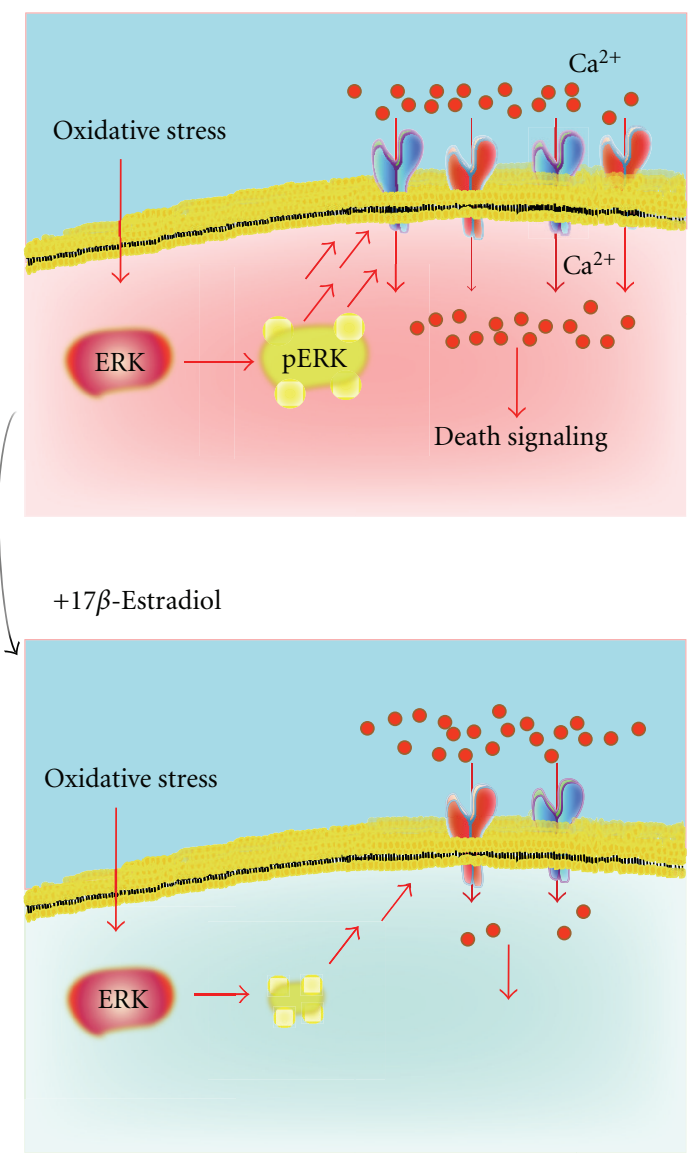

FIGURE 3: $17 \beta$-estradiol inhibits neuronal cell death under oxidative stress via reducing the series of events evoked by exposure to $\mathrm{H}_{2} \mathrm{O}_{2}$, including overactivation of the ERK signaling and overload of $\mathrm{Ca}^{2+}$. Upper: After $\mathrm{H}_{2} \mathrm{O}_{2}$ addition, marked phosphorylated (activated) ERK (pERK) and resultant increase in intracellular $\mathrm{Ca}^{2+}$ concentration were observed, resulting in cell death. Lower: Pretreatment with $17 \beta$-estradiol induced downregulation of ionotropic glutamate receptors via decreasing ERK activation, while also serving to decrease levels of $\mathrm{Ca}^{2+}$ influx triggered by $\mathrm{H}_{2} \mathrm{O}_{2}$. Such a decrease in glutamate receptor expression and intracellular $\mathrm{Ca}^{2+}$ was also confirmed in the presence of U0126, an inhibitor of ERK signaling. As expected, chronic $17 \beta$-estradiol reduced levels of pERK stimulated by $\mathrm{H}_{2} \mathrm{O}_{2}$. A blockade of glutamate receptors rescued cortical cells from $\mathrm{H}_{2} \mathrm{O}_{2}$-dependent death. Therefore, it is possible that $17 \beta$-estradiol promotes survival via suppressing glutamate receptor-mediated $\mathrm{Ca}^{2+}$ influx, due to downregulation of ionotropic glutamate receptors [120].

stimulated by $\mathrm{H}_{2} \mathrm{O}_{2}$. Furthermore, inhibitors of ionotropic glutamate receptors blocked cell death caused by $\mathrm{H}_{2} \mathrm{O}_{2}$. Taken together, it is possible that E2 exerts survivalpromoting effects through repressing glutamate receptormediated $\mathrm{Ca}^{2+}$ influx [120] (Figure 3). As described, ERK signaling is essential for maintenance of glutamate receptor levels, making it interesting to investigate how estrogens influence ERK signaling.

p66 $6^{\text {Shc }}$ also generates mitochondrial $\operatorname{ROS}\left(\mathrm{H}_{2} \mathrm{O}_{2}\right)$, causes impairment in $\mathrm{Ca}^{2+}$ homeostasis, and is associated with apoptosis [135, 136]. Almeida et al. found that $\mathrm{H}_{2} \mathrm{O}_{2}$ stimulates $\mathrm{PKC} \beta / \mathrm{p}^{\mathrm{S}} 6^{\mathrm{Shc}} / \mathrm{NF}-\kappa \mathrm{B}$ signaling to apoptosis in osteoblastic cells, and that $\mathrm{E} 2$ prevents $\mathrm{H}_{2} \mathrm{O}_{2}$-dependent activation of $\mathrm{p} 66^{\text {Shc }}$ and NF- $\kappa \mathrm{B}$ via repressing phosphorylation of $\mathrm{PKC} \beta$, resulting in protection from cell death [137].

\section{Estrogen In Vivo Approach}

In 6-hydroxydopamine (6-OHDA, a PD mimetic)-lesioned rats, a neuroprotective effect of silymarin (SM, one of flavonolignans) was shown [138]. SM administration protected neurons of the substantia nigra pars compacta from 6OHDA toxicity, while fulvestrant, an ER antagonist, partially blocked the effects of SM. Additionally, the effect of oral estrogen on ROS generation was reported. Wing et al. demonstrated a beneficial effect of chronic oral estrogen treatment on oxidative stress and atherosclerosis in apoEdeficient mice [139]. Using ovariectomized apoE-deficient mice, it was revealed that atherosclerosis was reduced when treated with E2 $(6 \mu \mathrm{g} /$ day $)$ for 12 weeks. Importantly, after E2 treatment, superoxide anion and expression of Nox decreased, while $\mathrm{Cu} / \mathrm{ZnSOD}$ and MnSOD increased [139]. Last, Schwann cells (SC) play a critical role in spinal cord injury repair, though SC survival after transplantation is very difficult. Current research is focused on discovering if E2 pretreatment protects SC, in an effort to generate more successful spinal cord transplantation procedures [140]. In primary SC cultures, strong expression of $\mathrm{ER} \alpha$ and $\mathrm{ER} \beta$, and overall E2-dependent survival mechanisms against $\mathrm{H}_{2} \mathrm{O}_{2}$ exposure were confirmed, though ICI182780 (an ER antagonist) had no influence on E2 effects. These findings suggest that genomic signaling via ERs is not involved. Importantly, in spinal cord injury, sustained E2 administration was found to be an effective treatment improving SC transplantation [140].

\section{Conclusion}

An increase in neuronal damage at the cellular and molecular level may be involved in the pathogenesis of brain illness, including neurodegenerative disease. It is possible that oxidative stress leads to neuronal cell death via increasing glutamate-mediated excitotoxicity, intracellular $\mathrm{Ca}^{2+}$ concentration, mitochondrial dysfunction, activation of deathsignaling cascades, and decreasing overall survival signaling. Several drug candidates, which were found to attenuate deleterious symptoms in various models of neurodegenerative disease, are reported to upregulate the expression of neurotrophic factors including BDNF. Considering this, it seems pertinent to further investigate the possible mechanisms underlying such neurotrophic factor upregulation. On the other hand, estrogenic survival promotion is also well studied, though further investigation addressing how each ER contributes to neuronal protection against oxidative toxicity is needed. Finally, as a close relationship between steroid hormones and BDNF in various neuronal functions including cell survival is known [141], detailed studies concerning how estrogen and BDNF interact with each other in CNS neurons under oxidative stress are important. 


\section{Acknowledgments}

This work was supported by a grant from the Core Research for Evolutional Science and Technology Program (CREST) Japan Science and Technology Agency (JST) (T. N., T. M., S. Y. and H. K.), the Takeda Science Foundation (T. N.), the Japan Health Sciences Foundation (Research on Health Sciences focusing on Drug Innovation) (H. K.), Health and Labor Sciences Research Grants (Comprehensive Research on Disability, Health, and Welfare) (H. K.), Intramural Research Grants (20-3, 21-9) for Neurological and Psychiatric Disorders of NCNP (H. K.), and Grants-in-Aid for Scientific Research (B) (grant number 20390318) (H. K.) and Young Scientists (A) (21680034) (T. N.) from the Ministry of Education, Culture, Sports, Science, and Technology of Japan.

\section{References}

[1] O. Sakurada, C. Kennedy, J. Jehle, J. D. Brown, G. L. Carbin, and L. Sokoloff, "Measurement of local cerebral blood flow with iodo [14C] antipyrine," The American Journal of Physiology, vol. 234, no. 1, pp. H59-H66, 1978.

[2] J. E. Cremer and M. P. Seville, "Regional brain blood flow, blood volume, and haematocrit values in the adult rat," Journal of Cerebral Blood Flow and Metabolism, vol. 3, no. 2, pp. 254-256, 1983.

[3] O. U. Scremin, R. R. Sonnenschein, and E. H. Rubinstein, "Cholinergic cerebral vasodilatation: lack of involvement of cranial parasympathetic nerves," Journal of Cerebral Blood Flow and Metabolism, vol. 3, no. 3, pp. 362-368, 1983.

[4] L. Sokoloff, M. Reivich, C. Kennedy et al., "The [C]deoxyglucose method for the measurement of local cerebral glucose utilization: theory, procedure, and normal values in the conscious and anesthetized albino rat," Journal of Neurochemistry, vol. 28, no. 5, pp. 897-916, 1977.

[5] L. Sokoloff, "Localization of functional activity in the central nervous system by measurement of glucose utilization with radioactive deoxyglucose," Journal of Cerebral Blood Flow and Metabolism, vol. 1, no. 1, pp. 7-36, 1981.

[6] T. Satoh, Y. Enokido, T. Kubo, M. Yamada, and H. Hatanaka, "Oxygen toxicity induces apoptosis in neuronal cells," Cellular and Molecular Neurobiology, vol. 18, no. 6, pp. 649-666, 1998.

[7] J. K. Andersen, "Oxidative stress in neurodegeneration: cause or consequence?” Nature Medicine, vol. 10, pp. S18-S25, 2004.

[8] D. Harman, "Free radical theory of aging: an updateincreasing the functional life span," Annals of the New York Academy of Sciences, vol. 1067, no. 1, pp. 10-21, 2006.

[9] E. Bossy-Wetzel, R. Schwarzenbacher, and S. A. Lipton, "Molecular pathways to neurodegeneration," Nature Medicine, vol. 10, no. 7, pp. S2-S9, 2004.

[10] E. J. Huang and L. F. Reichardt, "Trk receptors: roles in neuronal signal transduction," Annual Review of Biochemistry, vol. 72, pp. 609-642, 2003.

[11] T. Numakawa, S. Suzuki, E. Kumamaru, N. Adachi, M. Richards, and H. Kunugi, "BDNF function and intracellular signaling in neurons," Histology and Histopathology, vol. 25, no. 2, pp. 237-258, 2010.

[12] S. S. Gill, N. K. Patel, G. R. Hotton et al., "Direct brain infusion of glial cell line-derived neurotrophic factor in
Parkinson disease," Nature Medicine, vol. 9, no. 5, pp. 589595, 2003.

[13] F. Maina and R. Klein, "Hepatocyte growth factor, a versatile signal for developing neurons," Nature Neuroscience, vol. 2, no. 3, pp. 213-217, 1999.

[14] R. D. Brinton, "Estrogen-induced plasticity from cells to circuits: predictions for cognitive function," Trends in Pharmacological Sciences, vol. 30, no. 4, pp. 212-222, 2009.

[15] A. W. Lee and D. W. Pfaff, "Hormone effects on specific and global brain functions," Journal of Physiological Sciences, vol. 58, no. 4, pp. 213-220, 2008.

[16] S. Tobet, J. G. Knoll, C. Hartshorn et al., "Brain sex differences and hormone influences: a moving experience?" Journal of Neuroendocrinology, vol. 21, no. 4, pp. 387-392, 2009.

[17] J. W. Simpkins, K. D. Yi, S. H. Yang, and J. A. Dykens, "Mitochondrial mechanisms of estrogen neuroprotection," Biochimica et Biophysica Acta, vol. 1800, no. 10, pp. 11131120,2010

[18] K. T. Kishida and E. Klann, "Sources and targets of reactive oxygen species in synaptic plasticity and memory," Antioxidants and Redox Signaling, vol. 9, no. 2, pp. 233-244, 2007.

[19] D. A. Butterfield, T. Reed, S. F. Newman, and R. Sultana, "Roles of amyloid $\beta$-peptide-associated oxidative stress and brain protein modifications in the pathogenesis of Alzheimer's disease and mild cognitive impairment," Free Radical Biology and Medicine, vol. 43, no. 5, pp. 658-677, 2007.

[20] X. Huang, C. S. Atwood, M. A. Hartshorn et al., “The A $\beta$ peptide of Alzheimer's disease directly produces hydrogen peroxide through metal ion reduction," Biochemistry, vol. 38, no. 24, pp. 7609-7616, 1999.

[21] X. Huang, M. P. Cuajungco, C. S. Atwood et al., "Cu(II) potentiation of Alzheimer $\mathrm{A} \beta$ neurotoxicity. Correlation with cell-free hydrogen peroxide production and metal reduction," Journal of Biological Chemistry, vol. 274, no. 52, pp. 37111-37116, 1999.

[22] D. Jiang, L. Men, J. Wang et al., "Redox reactions of copper complexes formed with different $\beta$-amyloid peptides and their neuropathalogical relevance," Biochemistry, vol. 46, no. 32, pp. 9270-9282, 2007.

[23] R. C. Nadal, S. E. J. Rigby, and J. H. Viles, "Amyloid $\beta-\mathrm{Cu}^{2+}$ complexes in both monomeric and fibrillar forms do not generate $\mathrm{H}_{2} \mathrm{O}_{2}$ catalytically but quench hydroxyl radicals," Biochemistry, vol. 47, no. 44, pp. 11653-11664, 2008.

[24] C. Zhou, Y. Huang, and S. Przedborski, "Oxidative stress in Parkinson's disease: a mechanism of pathogenic and therapeutic significance," Annals of the New York Academy of Sciences, vol. 1147, pp. 93-104, 2008.

[25] Z. Qin, D. Hu, S. Han, S. H. Reaney, D. A. Di Monte, and A. L. Fink, "Effect of 4-hydroxy-2-nonenal modification on $\alpha$ synuclein aggregation," Journal of Biological Chemistry, vol. 282, no. 8, pp. 5862-5870, 2007.

[26] E. C. Stack, W. R. Matson, and R. J. Ferrante, "Evidence of oxidant damage in Huntington's disease: translational strategies using antioxidants," Annals of the New York Academy of Sciences, vol. 1147, pp. 79-92, 2008.

[27] X. Li, A. Valencia, E. Sapp et al., "Aberrant rab 11-dependent trafficking of the neuronal glutamate transporter EAACl causes oxidative stress and cell death in huntington's disease," Journal of Neuroscience, vol. 30, no. 13, pp. 4552-4561, 2010.

[28] N. A. Bishop, T. Lu, and B. A. Yankner, "Neural mechanisms of ageing and cognitive decline," Nature, vol. 464, no. 7288, pp. 529-535, 2010. 
[29] D. G. Nicholls, "Oxidative stress and energy crises in neuronal dysfunction," Annals of the New York Academy of Sciences, vol. 1147, pp. 53-60, 2008.

[30] V. Adam-Vizi and A. A. Starkov, "Calcium and mitochondrial reactive oxygen species generation: how to read the facts," Journal of Alzheimer's Disease, vol. 20, supplment 2, pp. S413S426, 2010.

[31] C. Henchcliffe and F. M. Beal, "Mitochondrial biology and oxidative stress in Parkinson disease pathogenesis," Nature Clinical Practice Neurology, vol. 4, no. 11, pp. 600-609, 2008.

[32] J. M. Gil and A. C. Rego, "Mechanisms of neurodegeneration in Huntington's disease," European Journal of Neuroscience, vol. 27, no. 11, pp. 2803-2820, 2008.

[33] K. Niizuma, H. Endo, and P. H. Chan, "Oxidative stress and mitochondrial dysfunction as determinants of ischemic neuronal death and survival," Journal of Neurochemistry, vol. 109, no. 1, pp. 133-138, 2009.

[34] D. Ben-Shachar and D. Laifenfeld, "Mitochondria, synaptic plasticity, and schizophrenia," International Review of Neurobiology, vol. 59, pp. 273-296, 2004.

[35] A. Gardner and R. G. Boles, "Beyond the serotonin hypothesis: mitochondria, inflammation and neurodegeneration in major depression and affective spectrum disorders," Progress in Neuro-Psychopharmacology \& Biological Psychiatry, vol. 35, no. 3, pp. 730-743, 2011.

[36] T. Kato, "Role of mitochondrial DNA in calcium signaling abnormality in bipolar disorder," Cell Calcium, vol. 44, no. 1, pp. 92-102, 2008.

[37] J. M. A. Oliveira, M. B. Jekabsons, S. Chen et al., "Mitochondrial dysfunction in Huntington's disease: the bioenergetics of isolated and in situ mitochondria from transgenic mice," Journal of Neurochemistry, vol. 101, no. 1, pp. 241-249, 2007.

[38] S. Gandhi, A. Wood-Kaczmar, Z. Yao et al., "PINK1associated Parkinson's disease is caused by neuronal vulnerability to calcium-induced cell death," Molecular Cell, vol. 33, no. 5, pp. 627-638, 2009.

[39] H. Tu, O. Nelson, A. Bezprozvanny et al., "Presenilins form ER $\mathrm{Ca}^{2+}$ leak channels, a function disrupted by familial Alzheimer's disease-linked mutations," Cell, vol. 126, no. 5, pp. 981-993, 2006.

[40] H. Zhang, S. Sun, A. Herreman, B. De Strooper, and I. Bezprozvanny, "Role of presenilins in neuronal calcium homeostasis," Journal of Neuroscience, vol. 30, no. 25, pp. 8566-8580, 2010.

[41] K. H. Cheung, D. Shineman, M. Müller et al., "Mechanism of $\mathrm{Ca}^{2+}$ disruption in Alzheimer's disease by presenilin regulation of InsP3 receptor channel gating," Neuron, vol. 58, no. 6, pp. 871-883, 2008.

[42] K. V. Kuchibhotla, S. T. Goldman, C. R. Lattarulo, H. Y. Wu, B. T. Hyman, and B. J. Bacskai, "A $\beta$ plaques lead to aberrant regulation of calcium homeostasis in vivo resulting in structural and functional disruption of neuronal networks," Neuron, vol. 59, no. 2, pp. 214-225, 2008.

[43] A. M. Brennan, S. W. Suh, S. J. Won et al., "NADPH oxidase is the primary source of superoxide induced by NMDA receptor activation," Nature Neuroscience, vol. 12, no. 7, pp. 857-863, 2009.

[44] H. Chen, Y. S. Song, and P. H. Chan, "Inhibition of NADPH oxidase is neuroprotective after ischemia-reperfusion," Journal of Cerebral Blood Flow and Metabolism, vol. 29, no. 7, pp. 1262-1272, 2009.

[45] D. W. Choi, "Neurodegeneration: cellular defences destroyed," Nature, vol. 433, no. 7027, pp. 696-698, 2005.
[46] D. Steckley, M. Karajgikar, L. B. Dale et al., "Puma is a dominant regulator of oxidative stress induced bax activation and neuronal apoptosis," Journal of Neuroscience, vol. 27, no. 47, pp. 12989-12999, 2007.

[47] K. Niizuma, H. Endo, C. Nito, D. J. Myer, and P. H. Chan, "Potential role of PUMA in delayed death of hippocampal CA1 neurons after transient global cerebral ischemia," Stroke, vol. 40, no. 2, pp. 618-625, 2009.

[48] S. J. Riedl and G. S. Salvesen, "The apoptosome: signalling platform of cell death," Nature Reviews Molecular Cell Biology, vol. 8, no. 5, pp. 405-413, 2007.

[49] C. Candé, F. Cecconi, P. Dessen, and G. Kroemer, "Apoptosisinducing factor (AIF): key to the conserved caspaseindependent pathways of cell death?" Journal of Cell Science, vol. 115, no. 24, pp. 4727-4734, 2002.

[50] K. Aoyama, W. S. Sang, A. M. Hamby et al., "Neuronal glutathione deficiency and age-dependent neurodegeneration in the EAAC1 deficient mouse," Nature Neuroscience, vol. 9, no. 1, pp. 119-126, 2006.

[51] A. E. Berman, W. Y. Chan, A. M. Brennan et al., "Nacetylcysteine prevents loss of dopaminergic neurons in the EAAC1(-/-) mouse," Annals of Neurology, vol. 69, no. 3, pp. 509-520, 2011.

[52] M. Kairisalo, A. Bonomo, A. Hyrskyluoto et al., "Resveratrol reduces oxidative stress and cell death and increases mitochondrial antioxidants and XIAP in PC6.3-cells," Neuroscience Letters, vol. 488, no. 3, pp. 263-266, 2011.

[53] S. Fallarini, G. Miglio, T. Paoletti et al., "Clovamide and rosmarinic acid induce neuroprotective effects in in vitro models of neuronal death," British Journal of Pharmacology, vol. 157, no. 6, pp. 1072-1084, 2009.

[54] Y. Shimojo, K. Kosaka, Y. Noda, T. Shimizu, and T. Shirasawa, "Effect of rosmarinic acid in motor dysfunction and life span in a mouse model of familial amyotrophic lateral sclerosis," Journal of Neuroscience Research, vol. 88, no. 4, pp. 896-904, 2010.

[55] J. Chao, W. K. W. Lau, M. J. Huie et al., "A pro-drug of the green tea polyphenol (-)-epigallocatechin-3-gallate (EGCG) prevents differentiated SH-SY5Y cells from toxicity induced by 6-hydroxydopamine," Neuroscience Letters, vol. 469, no. 3, pp. 360-364, 2010.

[56] R. Lagoa, C. Lopez-Sanchez, A. K. Samhan-Arias, C. M. Gañan, V. Garcia-Martinez, and C. Gutierrez-Merino, "Kaempferol protects against rat striatal degeneration induced by 3-nitropropionic acid," Journal of Neurochemistry, vol. 111, no. 2, pp. 473-487, 2009.

[57] D. Luo, Q. Zhang, H. Wang et al., "Fucoidan protects against dopaminergic neuron death in vivo and in vitro," European Journal of Pharmacology, vol. 617, no. 1-3, pp. 33-40, 2009.

[58] J. Kim, H. J. Lee, and K. W. Lee, "Naturally occurring phytochemicals for the prevention of Alzheimer's disease," Journal of Neurochemistry, vol. 112, no. 6, pp. 1415-1430, 2010.

[59] W. Duan, Z. Guo, H. Jiang, M. Ware, X. J. Li, and M. P. Mattson, "Dietary restriction normalizes glucose metabolism and BDNF levels, slows disease progression, and increases survival in huntingtin mutant mice," Proceedings of the National Academy of Sciences of the United States of America, vol. 100, no. 5, pp. 2911-2916, 2003.

[60] I. Ferrer, E. Goutan, C. Marín, M. J. Rey, and T. Ribalta, "Brain-derived neurotrophic factor in Huntington disease," Brain Research, vol. 866, no. 1-2, pp. 257-261, 2000.

[61] S. Gines, I. S. Seong, E. Fossale et al., "Specific progressive cAMP reduction implicates energy deficit in presymptomatic 
Huntington's disease knock-in mice," Human Molecular Genetics, vol. 12, no. 5, pp. 497-508, 2003.

[62] S. Ginés, M. Bosch, S. Marco et al., "Reduced expression of the TrkB receptor in Huntington's disease mouse models and in human brain," European Journal of Neuroscience, vol. 23, no. 3, pp. 649-658, 2006.

[63] S. Ginés, P. Paoletti, and J. Alberch, "Impaired TrkBmediated ERK1/2 activation in huntington disease knockin striatal cells involves reduced p52/p46 Shc expression," Journal of Biological Chemistry, vol. 285, no. 28, pp. 2153721548, 2010.

[64] E. Perez-Navarro, A. M. Canudas, P. Akerud, J. Alberch, and E. Arenas, "Brain-derived neurotrophic factor, neurotrophin-3, and neurotrophin-4/5 prevent the death of striatal projection neurons in a rodent model of Huntington's disease," Journal of Neurochemistry, vol. 75, no. 5, pp. 2190-2199, 2000.

[65] S. E. Counts and E. J. Mufson, "Noradrenaline activation of neurotrophic pathways protects against neuronal amyloid toxicity," Journal of Neurochemistry, vol. 113, no. 3, pp. 649660,2010

[66] H. Cheng, J. Yu, Z. Jiang et al., "Acupuncture improves cognitive deficits and regulates the brain cell proliferation of SAMP8 mice," Neuroscience Letters, vol. 432, no. 2, pp. 111116,2008

[67] H. Zhao, Q. Li, Z. Zhang, X. Pei, J. Wang, and Y. Li, "Longterm ginsenoside consumption prevents memory loss in aged SAMP8 mice by decreasing oxidative stress and upregulating the plasticity-related proteins in hippocampus," Brain Research, vol. 1256, no. C, pp. 111-122, 2009.

[68] S. Y. Hung, H. C. Liou, K. H. Kang, R. M. Wu, C. C. Wen, and W. M. Fu, "Overexpression of heme oxygenase1 protects dopaminergic neurons against 1-methyl-4phenylpyridinium-induced neurotoxicity," Molecular Pharmacology, vol. 74, no. 6, pp. 1564-1575, 2008.

[69] S. Y. Hung, H. C. Liou, and W. M. Fu, "The mechanism of heme oxygenase-1 action involved in the enhancement of neurotrophic factor expression," Neuropharmacology, vol. 58, no. 2, pp. 321-329, 2010.

[70] C. Li, S. Biswas, X. Li, A. K. Dutta, and W. Le, "Novel D3 dopamine receptor-preferring agonist D-264: evidence of neuroprotective property in Parkinson's disease animal models induced by 1-methyl-4-phenyl-1,2,3,6tetrahydropyridine and lactacystin," Journal of Neuroscience Research, vol. 88, no. 11, pp. 2513-2523, 2010.

[71] H. S. Cho, S. Kim, S. Y. Lee, J. A. Park, S. J. Kim, and H. S. Chun, "Protective effect of the green tea component, 1-theanine on environmental toxins-induced neuronal cell death," NeuroToxicology, vol. 29, no. 4, pp. 656-662, 2008.

[72] S. Takai, M. Yamada, T. Araki, H. Koshimizu, H. Nawa, and H. Hatanaka, "Shp-2 positively regulates brain-derived neurotrophic factor-promoted survival of cultured ventral mesencephalic dopaminergic neurons through a brain immunoglobulin-like molecule with tyrosine-based activation motifs/Shp substrate-1," Journal of Neurochemistry, vol. 82, no. 2, pp. 353-364, 2002.

[73] S. Love, P. Plaha, N. K. Patel, G. R. Hotton, D. J. Brooks, and S. S. Gill, "Glial cell line-derived neurotrophic factor induces neuronal sprouting in human brain," Nature Medicine, vol. 11, no. 7, pp. 703-704, 2005.

[74] T. Numakawa, E. Kumamaru, N. Adachi, Y. Yagasaki, A. Izumi, and H. Kunugi, "Glucocorticoid receptor interaction with TrkB promotes BDNF-triggered PLC- $\gamma$ signaling for glutamate release via a glutamate transporter," Proceedings of the National Academy of Sciences of the United States of America, vol. 106, no. 2, pp. 647-652, 2009.

[75] A. Woronowicz, S. R. Amith, V. W. Davis et al., "Trypanosome trans-sialidase mediates neuroprotection against oxidative stress, serum/glucose deprivation, and hypoxiainduced neurite retraction in Trk-expressing PC12 cells," Glycobiology, vol. 17, no. 7, pp. 725-734, 2007.

[76] N. Boutahar, E. Reynaud, F. Lassabliere, and J. Borg, "Brainderived neurotrophic factor inhibits cell cycle reentry but not endoplasmic reticulum stress in cultured neurons following oxidative or excitotoxic stress," Journal of Neuroscience Research, vol. 88, no. 10, pp. 2263-2271, 2010.

[77] B. Lee, R. Cao, Y. S. Choi et al., "The CREB/CRE transcriptional pathway: protection against oxidative stress-mediated neuronal cell death," Journal of Neurochemistry, vol. 108, no. 5, pp. 1251-1265, 2009.

[78] B. E. Lonze and D. D. Ginty, "Function and regulation of CREB family transcription factors in the nervous system," Neuron, vol. 35, no. 4, pp. 605-623, 2002.

[79] T. Aid, A. Kazantseva, M. Piirsoo, K. Palm, and T. Timmusk, "Mouse and rat BDNF gene structure and expression revisited," Journal of Neuroscience Research, vol. 85, no. 3, pp. 525535, 2007.

[80] E. J. Hong, A. E. McCord, and M. E. Greenberg, "A biological function for the neuronal activity-dependent component of Bdnf transcription in the development of cortical inhibition," Neuron, vol. 60, no. 4, pp. 610-624, 2008.

[81] S. J. Allen and D. Dawbarn, "Clinical relevance of the neurotrophins and their receptors," Clinical Science, vol. 110, no. 2, pp. 175-191, 2006.

[82] B. S. Choi, K. Sapkota, S. Kim, H. J. Lee, H. S. Choi, and S. J. Kim, "Antioxidant activity and protective effects of tripterygium regelii extract on hydrogen peroxide-induced injury in human dopaminergic cells, SH-SY5Y," Neurochemical Research, vol. 35, no. 8, pp. 1269-1280, 2010.

[83] J. E. Hooper and M. P. Scott, "Communicating with hedgehogs," Nature Reviews Molecular Cell Biology, vol. 6, no. 4, pp. 306-317, 2005.

[84] R. L. Dai, S. Y. Zhu, Y. P. Xia et al., "Sonic hedgehog protects cortical neurons against oxidative stress," Neurochemical Research, vol. 36, no. 1, pp. 67-75, 2011.

[85] S. Khanna, S. Roy, H. Ryu et al., "Molecular basis of vitamin $\mathrm{E}$ action: tocotrienol modulates 12-lipoxygenase, a key mediator of glutamate-induced neurodegeneration," Journal of Biological Chemistry, vol. 278, no. 44, pp. 4350843515, 2003.

[86] T. B. Sherer, R. Betarbet, C. M. Testa et al., "Mechanism of toxicity in rotenone models of Parkinson's disease," Journal of Neuroscience, vol. 23, no. 34, pp. 10756-10764, 2003.

[87] F. Osakada, A. Hashino, T. Kume, H. Katsuki, S. Kaneko, and A. Akaike, " $\alpha$-tocotrienol provides the most potent neuroprotection among vitamin $\mathrm{E}$ analogs on cultured striatal neurons," Neuropharmacology, vol. 47, no. 6, pp. 904915, 2004.

[88] V. Conte, K. Uryu, S. Fujimoto et al., "Vitamin E reduces amyloidosis and improves cognitive function in $\operatorname{Tg} 2576$ mice following repetitive concussive brain injury," Journal of Neurochemistry, vol. 90, no. 3, pp. 758-764, 2004.

[89] H. Nakashima, T. Ishihara, O. Yokota et al., "Effects of $\alpha$ tocopherol on an animal model of tauopathies," Free Radical Biology and Medicine, vol. 37, no. 2, pp. 176-186, 2004.

[90] A. Kontush and S. Schekatolina, "Vitamin E in neurodegenerative disorders: Alzheimer's disease," Annals of the New York Academy of Sciences, vol. 1031, pp. 249-262, 2004. 
[91] D. Praticò, "Evidence of oxidative stress in Alzheimer's disease brain and antioxidant therapy: lights and shadows," Annals of the New York Academy of Sciences, vol. 1147, pp. 70-78, 2008.

[92] Y. Numakawa, T. Numakawa, T. Matsumoto et al., "Vitamin E protected cultured cortical neurons from oxidative stressinduced cell death through the activation of mitogenactivated protein kinase and phosphatidylinositol 3-kinase," Journal of Neurochemistry, vol. 97, no. 4, pp. 1191-1202, 2006.

[93] P. B. Shieh, S. C. Hu, K. Bobb, T. Timmusk, and A. Ghosh, "Identification of a signaling pathway involved in calcium regulation of BDNF expression," Neuron, vol. 20, no. 4, pp. 727-740, 1998.

[94] X. Tao, S. Finkbeiner, D. B. Arnold, A. J. Shaywitz, and M. E. Greenberg, " $\mathrm{Ca}^{2+}$ influx regulates BDNF transcription by a CREB family transcription factor-dependent mechanism," Neuron, vol. 20, no. 4, pp. 709-726, 1998.

[95] B. J. Gwag and J. E. Springer, "Activation of NMDA receptors increases brain-derived neurotrophic factor (BDNF) mRNA expression in the hippocampal formation," NeuroReport, vol. 5, no. 2, pp. 125-128, 1993.

[96] M. Hartmann, R. Heumann, and V. Lessmann, "Synaptic secretion of BDNF after high-frequency stimulation of glutamatergic synapses," EMBO Journal, vol. 20, no. 21, pp. 5887-5897, 2001.

[97] A. Balkowiec and D. M. Katz, "Activity-dependent release of endogenous brain-derived neurotrophic factor from primary sensory neurons detected by ELISA in situ," Journal of Neuroscience, vol. 20, no. 19, pp. 7417-7423, 2000.

[98] A. Balkowiec and D. M. Katz, "Cellular mechanisms regulating activity-dependent release of native brain-derived neurotrophic factor from hippocampal neurons," Journal of Neuroscience, vol. 22, no. 23, pp. 10399-10407, 2002.

[99] M. E. Greenberg, B. Xu, B. Lu, and B. L. Hempstead, "New insights in the biology of BDNF synthesis and release: implications in CNS function," Journal of Neuroscience, vol. 29, no. 41, pp. 12764-12767, 2009.

[100] S. W. Flavell and M. E. Greenberg, "Signaling mechanisms linking neuronal activity to gene expression and plasticity of the nervous system," Annual Review of Neuroscience, vol. 31, pp. 563-590, 2008.

[101] D. Lau and H. Bading, "Synaptic activity-mediated suppression of p53 and induction of nuclear calcium-regulated neuroprotective genes promote survival through inhibition of mitochondrial permeability transition," Journal of Neuroscience, vol. 29, no. 14, pp. 4420-4429, 2009.

[102] F. Léveillé, S. Papadia, M. Fricker et al., "Suppression of the intrinsic apoptosis pathway by synaptic activity," Journal of Neuroscience, vol. 30, no. 7, pp. 2623-2635, 2010.

[103] I. Túnez, R. Drucker-Colín, I. Jimena et al., "Transcranial magnetic stimulation attenuates cell loss and oxidative damage in the striatum induced in the 3-nitropropionic model of Huntington's disease," Journal of Neurochemistry, vol. 97, no. 3, pp. 619-630, 2006.

[104] G. W. Cho, S. H. Koh, M. H. Kim et al., "The neuroprotective effect of erythropoietin-transduced human mesenchymal stromal cells in an animal model of ischemic stroke," Brain Research, vol. 1353, pp. 1-13, 2010.

[105] D. Takeuchi, N. Sato, M. Shimamura et al., "Alleviation of $\mathrm{A} \beta$-induced cognitive impairment by ultrasound-mediated gene transfer of HGF in a mouse model," Gene Therapy, vol. 15 , no. 8, pp. 561-571, 2008.
[106] R. D. Brinton, "Cellular and molecular mechanisms of estrogen regulation of memory function and neuroprotection against Alzheimer's disease: recent insights and remaining challenges," Learning and Memory, vol. 8, no. 3, pp. 121-133, 2001.

[107] K. Kurata, M. Takebayashi, S. Morinobu, and S. Yamawaki, " $\beta$-estradiol, dehydroepiandrosterone, and dehydroepiandrosterone sulfate protect against N-methyl-D-aspartateinduced neurotoxicity in rat hippocampal neurons by different mechanisms," Journal of Pharmacology and Experimental Therapeutics, vol. 311, no. 1, pp. 237-245, 2004.

[108] J. W. Simpkins and J. A. Dykens, "Mitochondrial mechanisms of estrogen neuroprotection," Brain Research Reviews, vol. 57, no. 2, pp. 421-430, 2008.

[109] S. Liu and F. Mauvais-Jarvis, "Minireview: estrogenic protection of $\beta$-cell failure in metabolic diseases," Endocrinology, vol. 151, no. 3, pp. 859-864, 2010.

[110] J. W. Simpkins, K. D. Yi, and S. H. Yang, "Role of protein phosphatases and mitochondria in the neuroprotective effects of estrogens," Frontiers in Neuroendocrinology, vol. 30, no. 2, pp. 93-105, 2009.

[111] G. G. J. M. Kuiper, E. Enmark, M. Pelto-Huikko, S. Nilsson, and J. A. Gustafsson, "Cloning of a novel estrogen receptor expressed in rat prostate and ovary," Proceedings of the National Academy of Sciences of the United States of America, vol. 93, no. 12, pp. 5925-5930, 1996.

[112] C. Zhao, K. Dahlman-Wright, and J. A. Gustafsson, "Estrogen signaling via estrogen receptor $\beta$," The Journal of Biological Chemistry, vol. 285, no. 51, pp. 39575-39579, 2010.

[113] Q. G. Zhang, L. Raz, R. Wang et al., "Estrogen attenuates ischemic oxidative damage via an estrogen receptor $\alpha$ mediated inhibition of NADPH oxidase activation," Journal of Neuroscience, vol. 29, no. 44, pp. 13823-13836, 2009.

[114] Y. Xia, J. Z. Xing, and T. L. Krukoff, "Neuroprotective effects of R,R-tetrahydrochrysene against glutamate-induced cell death through anti-excitotoxic and antioxidant actions involving estrogen receptor-dependent and -independent pathways," Neuroscience, vol. 162, no. 2, pp. 292-306, 2009.

[115] S. H. Yang, S. N. Sarkar, R. Liu et al., "Estrogen receptor $\beta$ as a mitochondrial vulnerability factor," Journal of Biological Chemistry, vol. 284, no. 14, pp. 9540-9548, 2009.

[116] S. Gingerich, G. L. Kim, J. A. Chalmers et al., "Estrogen receptor alpha and G-protein coupled receptor 30 mediate the neuroprotective effects of $17 \beta$-estradiol in novel murine hippocampal cell models," Neuroscience, vol. 170, no. 1, pp. 54-66, 2010.

[117] T. Numakawa, S. Yamagishi, N. Adachi et al., "Brain-derived neurotrophic factor-induced potentiation of $\mathrm{Ca}^{2+}$ oscillations in developing cortical neurons," Journal of Biological Chemistry, vol. 277, no. 8, pp. 6520-6529, 2002.

[118] L. Zhang, B. E. Blackman, M. D. Schonemann et al., "Estrogen receptor $\beta$-selective agonists stimulate calcium oscillations in human and mouse embryonic stem cellderived neurons," PLoS ONE, vol. 5, no. 7, article e11791, 2010.

[119] D. Grove-Strawser, M. I. Boulware, and P. G. Mermelstein, "Membrane estrogen receptors activate the metabotropic glutamate receptors mGluR5 and mGluR3 to bidirectionally regulate CREB phosphorylation in female rat striatal neurons," Neuroscience, vol. 170, no. 4, pp. 1045-1055, 2010.

[120] Y. Numakawa, T. Matsumoto, D. Yokomaku et al., " $17 \beta-$ estradiol protects cortical neurons against oxidative stressinduced cell death through reduction in the activity of 
mitogen-activated protein kinase and in the accumulation of intracellular calcium," Endocrinology, vol. 148, no. 2, pp. 627637, 2007.

[121] N. Inamura, Y. Enokido, and H. Hatanaka, "Involvement of c-Jun N-terminal kinase and caspase 3-like protease in DNA damage-induced, p53-mediated apoptosis of cultured mouse cerebellar granule neurons," Brain Research, vol. 904, no. 2, pp. 270-278, 2001.

[122] S. L. Vallés, C. Borrás, J. Gambini et al., "Oestradiol or genistein rescues neurons from amyloid beta-induced cell death by inhibiting activation of p38," Aging Cell, vol. 7, no. 1, pp. 112-118, 2008.

[123] Y. Ishikawa, E. Kusaka, Y. Enokido, T. Ikeuchi, and H. Hatanaka, "Regulation of Bax translocation through phosphorylation at Ser-70 of Bcl-2 by MAP kinase in NO-induced neuronal apoptosis," Molecular and Cellular Neuroscience, vol. 24, no. 2, pp. 451-459, 2003.

[124] S. Yamagishi, T. Matsumoto, T. Numakawa et al., "ERK1/2 are involved in low potassium-induced apoptotic signaling downstream of ASK1-p38 MAPK pathway in cultured cerebellar granule neurons," Brain Research, vol. 1038, no. 2, pp. 223-230, 2005.

[125] E. K. Kim and E. J. Choi, "Pathological roles of MAPK signaling pathways in human diseases," Biochimica et Biophysica Acta, vol. 1802, no. 4, pp. 396-405, 2010.

[126] M. P. Mattson, "Apoptosis in neurodegenerative disorders," Nature Reviews Molecular Cell Biology, vol. 1, no. 2, pp. 120 $129,2000$.

[127] M. Stanciu, Y. Wang, R. Kentor et al., "Persistent activation of ERK contributes to glutamate-induced oxidative toxicity in a neuronal cell line and primary cortical neuron cultures," Journal of Biological Chemistry, vol. 275, no. 16, pp. 1220012206, 2000.

[128] A. J. Crossthwaite, S. Hasan, and R. J. Williams, "Hydrogen peroxide-mediated phosphorylation of ERK1/2, AKt/PKB and JNK in cortical neurones: dependence on $\mathrm{Ca}^{2+}$ and PI3kinase," Journal of Neurochemistry, vol. 80, no. 1, pp. 24-35, 2002.

[129] Y. Matsumoto, S. Yamamoto, Y. Suzuki et al., " $\mathrm{Na}^{+} / \mathrm{H}^{+}$ exchanger inhibitor, SM-20220, is protective against excitotoxicity in cultured cortical neurons," Stroke, vol. 35, no. 1, pp. 185-190, 2004.

[130] D. M. Hartley, M. C. Kurth, L. Bjerkness, J. H. Weiss, and D. W. Choi, "Glutamate receptor-induced ${ }^{45} \mathrm{Ca}^{2+}$ accumulation in cortical cell culture correlates with subsequent neuronal degeneration," Journal of Neuroscience, vol. 13, no. 5, pp. 1993-2000, 1993.

[131] J. H. Weiss, D. M. Hartley, J. Koh, and D. W. Choi, "The calcium channel blocker nifedipine attenuates slow excitatory amino acid neurotoxicity," Science, vol. 247, no. 4949 I, pp. 1474-1477, 1990.

[132] T. Matsumoto, T. Numakawa, D. Yokomaku et al., "Brainderived neurotrophic factor-induced potentiation of glutamate and GABA release: different dependency on signaling pathways and neuronal activity," Molecular and Cellular Neuroscience, vol. 31, no. 1, pp. 70-84, 2006.

[133] T. Tuerxun, T. Numakawa, N. Adachi et al., "SA4503, a sigma-1 receptor agonist, prevents cultured cortical neurons from oxidative stress-induced cell death via suppression of MAPK pathway activation and glutamate receptor expression," Neuroscience Letters, vol. 469, no. 3, pp. 303-308, 2010.

[134] H. Kawashima, T. Numakawa, E. Kumamaru et al., "Glucocorticoid attenuates brain-derived neurotrophic factordependent upregulation of glutamate receptors via the suppression of microRNA-132 expression," Neuroscience, vol. 165, no. 4, pp. 1301-1311, 2010.

[135] M. Giorgio, E. Migliaccio, F. Orsini et al., "Electron transfer between cytochrome $\mathrm{c}$ and $\mathrm{p} 66^{\text {Shc }}$ generates reactive oxygen species that trigger mitochondrial apoptosis," Cell, vol. 122, no. 2, pp. 221-233, 2005.

[136] M. Pellegrini, F. Finetti, V. Petronilli et al., "p $66^{\text {Shc }}$ promotes $\mathrm{T}$ cell apoptosis by inducing mitochondrial dysfunction and impaired $\mathrm{Ca}^{2+}$ homeostasis," Cell Death and Differentiation, vol. 14, no. 2, pp. 338-347, 2007.

[137] M. Almeida, L. Han, E. Ambrogini, S. M. Bartell, and S. C. Manolagas, "Oxidative stress stimulates apoptosis and activates NF- $\kappa$ B in osteoblastic cells via a PKC $\beta / \mathrm{p} 66^{\text {Shc }}$ signaling cascade: counter regulation by estrogens or androgens," Molecular Endocrinology, vol. 24, no. 10, pp. 2030-2037, 2010.

[138] T. Baluchnejadmojarad, M. Roghani, and M. Mafakheri, "Neuroprotective effect of silymarin in 6-hydroxydopamine hemi-parkinsonian rat: involvement of estrogen receptors and oxidative stress," Neuroscience Letters, vol. 480, no. 3, pp. 206-210, 2010.

[139] L. Y. C. Wing, Y. C. Chen, Y. Y. Shih, J. C. Cheng, Y. J. Lin, and M. J. Jiang, "Effects of oral estrogen on aortic ROSgenerating and -scavenging enzymes and atherosclerosis in apoE-deficient mice," Experimental Biology and Medicine, vol. 234, no. 9, pp. 1037-1046, 2009.

[140] A. Siriphorn, S. Chompoopong, and C. L. Floyd, " $17 \beta-$ estradiol protects Schwann cells against $\mathrm{H}_{2} \mathrm{O}_{2}$-induced cytotoxicity and increases transplanted Schwann cell survival in a cervical hemicontusion spinal cord injury model," Journal of Neurochemistry, vol. 115, no. 4, pp. 864-872, 2010.

[141] T. Numakawa, D. Yokomaku, M. Richards, H. Hori, N. Adachi, and H. Kunugi, "Functional interactions between steroid hormones and neurotrophin BDNF," World Journal of Biological Chemistry, vol. 1, no. 5, pp. 133-143, 2010. 

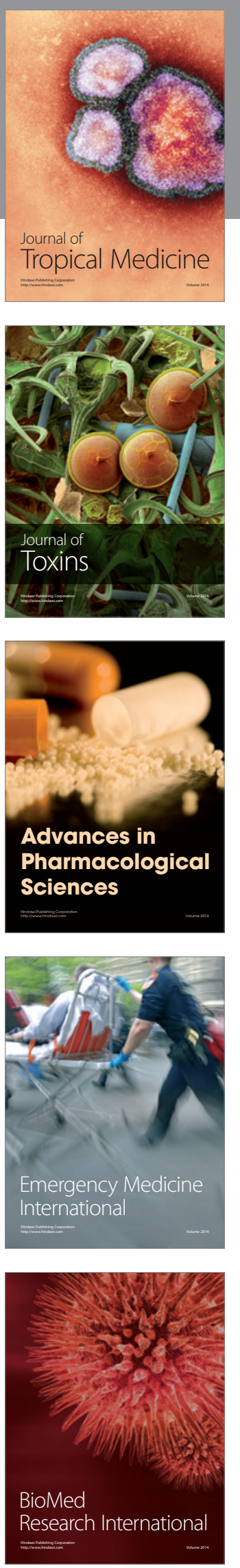
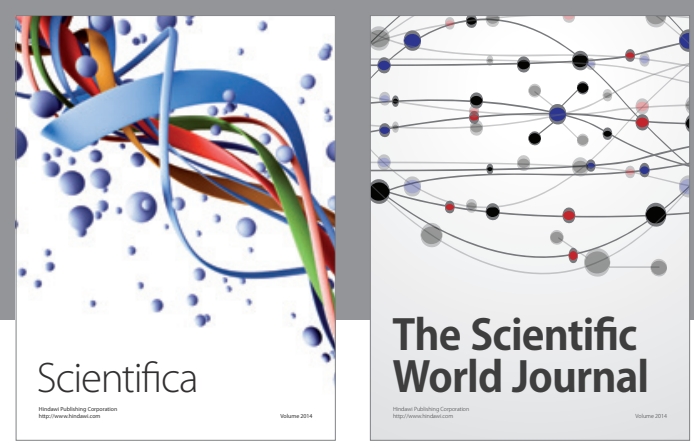

The Scientific World Journal
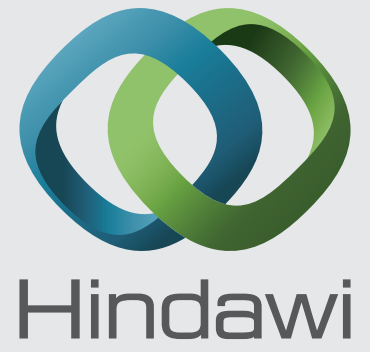

Submit your manuscripts at

http://www.hindawi.com
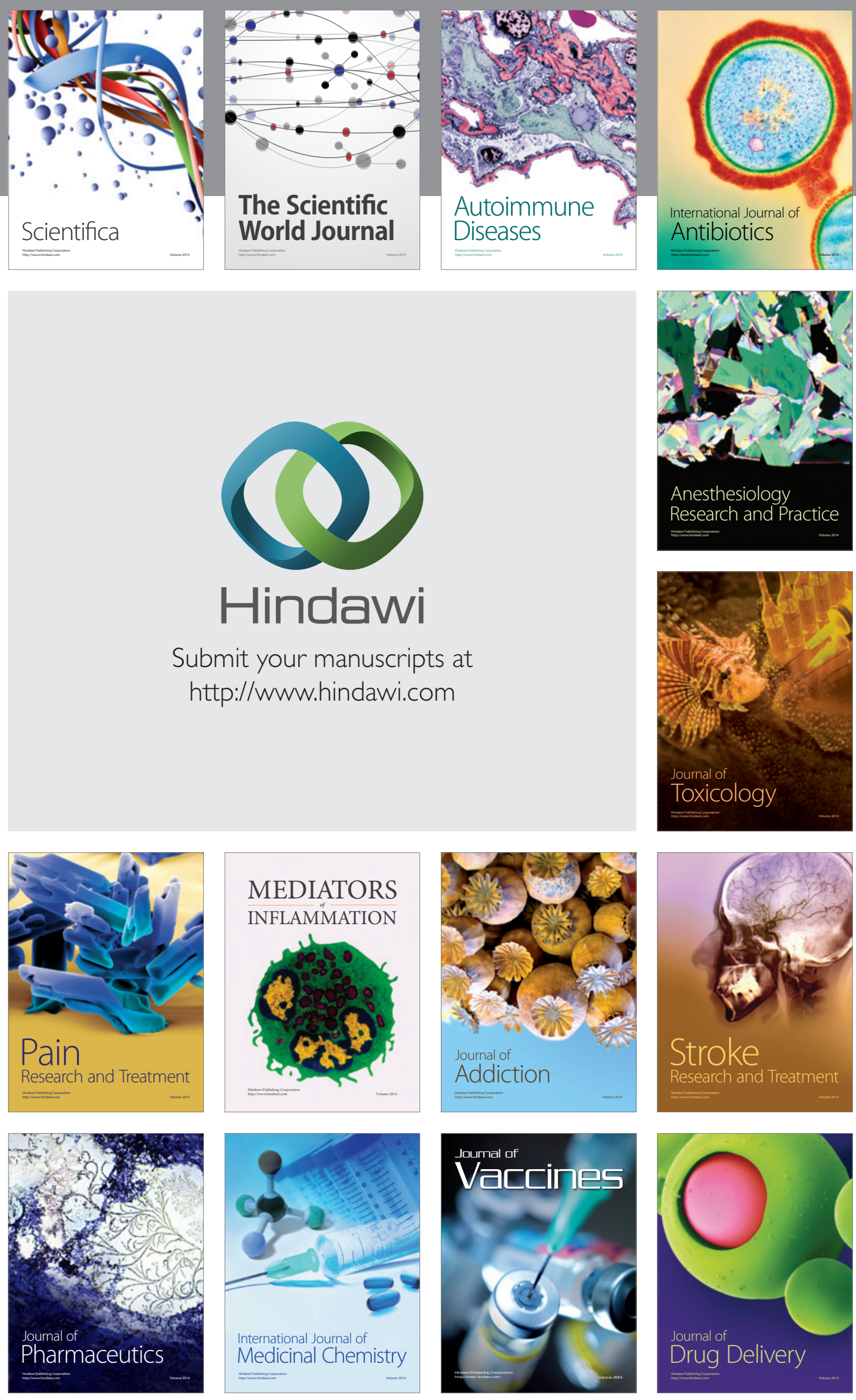